\title{
Mobile applications in women's health education in obstetric and gynecological care
}

\author{
Aplikacje mobilne w edukacji zdrowotnej kobiet w opiece położniczo-ginekologicznej
}

\author{
Monika Walec ${ }^{1}$, Natalia Surma' ${ }^{1}$, Weronika Michoń ${ }^{1}$, Barbara Ślusarska² ${ }^{\circ}$
}

\author{
'Student, undergraduate course in Midwifery, FoHS MU of Lublin/ \\ Koło Naukowe przy Katedrze Onkologii i Opieki Środowiskowej, WNoZ UM w Lublinie \\ 2Department of Family Medicine and Community Nursing, FoHS MU of Lublin/ \\ Zakład Medycyny Rodzinnej i Pielęgniarstwa Środowiskowego, WNoZ UM w Lublinie \\ CORRESPONDING AUTHOR/AUTOR DO KORESPONDENCJI: \\ Barbara Ślusarska \\ Zakład Medycyny Rodzinnej i Pielęgniarstwa Środowiskowego, WNoZ UM w Lublinie \\ ul. Staszica 4/6, 20-081 Lublin \\ e-mail: barbaraslusarska@umlub.pl
}

STRESZCZENIE

Słowa kluczowe:

ABSTRACT

Key words:

\section{APLIKACJE MOBILNEW EDUKACJI ZDROWOTNEJ KOBIET W OPIECE POROZNICZO-GINEKOLOGICZNE:}

Wprowadzenie. Dynamiczny rozwój nowych technologii i upowszechnienie aplikacji mobilnych w życiu codziennym stwarzają możliwości wykorzystywania nowej formy do działań w ramach edukacji zdrowotnej kobiet.

Cel. Celem pracy jest przegląd aplikacji mobilnych możliwych do wykorzystywania w edukacji zdrowotnej kobiet w opiece położniczoginekologicznej oraz określenie ich zakresu funkcji ułatwiających samodzielną kontrolę stanu zdrowia przez kobiety.

Materiał i metoda. W badaniach aplikacji mobilnych ograniczono się do aplikacji dostępnych dla systemu Android oraz systemu iOS (iPhone). Źródłem wszystkich informacji są strony producentów danego oprogramowania. Kryterium włączenia aplikacji do analizy było: aplikacja dostępna na stronie internetowej play.google.com oraz aplikacja przydatna w opiece położniczo-ginekologicznej kobiet. Spośród dostępnych do analiz włączono 27 aplikacji, które miały największą liczbę pobrań.

Wyniki. Ze względu na zakres merytoryczny edukacji zdrowotnej kobiet dokonano klasyfikacji aplikacji mobilnych na trzy grupy: 1). pomocne w kontroli cyklu miesiączkowego, 2). pomocne w trakcie monitorowania ciąży, 3). wykorzystywane w profilaktyce chorób w opiece ginekologiczno- położniczej. Spośród wszystkich dostępnych aplikacji wybrano po 10 pomocnych w kontroli cyklu miesiączkowego i w trakcie monitorowania ciąży oraz 7 wykorzystywanych w profilaktyce chorób w opiece ginekologiczno - położniczej.

Wnioski. W grupie analizowanych aplikacji pomocnych w kontroli cyklu miesiączkowego aż w 83\% posiada zakres funkcji oferowanych przez producentów i ułatwiających samodzielną kontrolę przez kobiety. Niższe wskaźniki funkcji (63\%) występują w grupie aplikacji pomocnych w monitorowaniu ciąży i jeszcze niższe w grupie profilaktyki chorób. Mobilne aplikacje zdrowotne stanowią obiecującą strategię edukacji zdrowotnej jako narzędzie monitorowania, poprawiania samokontroli oraz zwiększenia świadomości w opiece nad kobietami.

aplikacje mobilne, edukacja zdrowotna, kobiety, opieka położniczo-ginekologiczna

\section{MOBILE APPLICATIONS IN WOMEN'S HEALTH EDUCATION IN OBSTETRICAND GYNECOLOGICAL CARE}

Introduction. The dynamic development of new technologies and the dissemination of mobile applications in everyday life create opportunities for using the new form for activities within the framework of women's health education.

Aim. The work aims to review mobile applications that can be used in women's health education in obstetrics and gynecology, and to determine their range of functions facilitating independent control of women's health.

Material and method. The research of mobile applications was limited to the ones available for Android and iOS (iPhone). The source of all information are the websites of the software producers. The criteria for including the application in the analysis were: availability on the website play.google.com and usefulness in obstetric-gynecological care of women. As many as 27 applications with the highest number of downloads became the subject matter of the analysis.

Results. Due to the substantive scope of women's health education, mobile applications were classified into three groups: 1) helpful in controlling the menstrual cycle, 2) helpful in monitoring pregnancy, 3) used in the prevention of diseases in gynecological-obstetric care. Out of all the applications available, 10 were classified to the first and second group each, and 7 to the third one.

Conclusions. Mobile health applications are a promising strategy for health education as a tool for monitoring, improving self-control, and raising awareness in the care of women.

mobile applications, health education, women, obstetric and gynecological care 


\section{INTRODUCTION}

The dynamic development of new technologies and the dissemination of mobile applications in everyday life create opportunities for using the new form of activities within the framework of the health education of patients, including groups with special educational needs, i.e. women. Mobile applications, as software running on mobile devices such as smartphones, tablets and similar, gain particular recognition among young people, as well as adults. The devices facilitate, but also change the way of communication, influence decisions and significantly improve the quality of life [1]. They also become a special form of communication for the needs of health education. Their attractiveness and ease of use cause a considerable increase in interest and widespread use, supporting all aspects of life, including health education issues [2].

Mobile health (m-health) is a new and rapidly growing area that plays a vital role in the transformation of health care, which can be significant for the quality and efficiency of medical and educational services for patients. The mobile application market in health care is developing intensively. Currently, the highest number of mobile applications are related to pro-health physical activity (31\%), programs with medical information (about $17 \%$ ), so-called wellness - relaxation applications (over 15\%), nutritional applications (7\%), or health management programs $(7 \%)$. The $\mathrm{m}$-health application group also includes those targeted at specific groups of patients, e.g. with diabetes and other chronic diseases, adhering to therapeutic recommendations, or concerning first aid [3].

In 2017, over 325,000 health and medical applications were available in the Google Play Store and Apple AppStore [4].

Most mHealth applications concern improving your overall health. However, the number of programs for health management and diagnosis of diseases is increasing rapidly, currently constituting $40 \%$ of all the health-related applications. In 2017, those covering the thematic scope of women's health and pregnancy accounted for 9\% [5].

Innovative mHealth systems are not without their imperfections and threats. The attractive form and scope of the content of the mHealth application are combined with concerns about the security of such solutions and patients' independence in making decisions that may be incorrect or outdated [6]. Data security is also the main problem among health professionals when they recommend mobile applications to their clients [7].

Unfortunately, no clear regulations specifying which applications and to what extent should be subject to control before they reach the user's market can be found. To a limited extent, some doubts can be verified by browsing the European Directory of Health Apps, which collects and archives information on reliable health applications [8].

The work aims to review the selected mobile applications available for use in women's health education in obstetric and gynecological care and to determine their range of functions facilitating independent control of women's health.

\section{MATERIALS AND METHOD}

The research of mobile applications was limited to those available for Android and iOS (iPhone). In Poland, mobile medical programs are mostly acquired from the Google Play Store and AppStore. The source of all information are the websites of the software producers.

The criteria for including an application in the analysis were: availability on the website play.google.com and usefulness in obstetric-gynecological care of women. As many as 27 applications with the highest number of downloads became the subject matter of the analysis.

\section{RESULTS}

Due to the substantive scope of women's health education, mobile applications were classified into three groups: 1) menstrual cycle control, 2) pregnancy monitoring, 3) disease prevention in obstetric and gynecological care. Out of all the available applications, we selected 10 used for menstrual cycle control, 10 used for pregnancy monitoring, and 7 used in the prevention of diseases in gynecological and obstetric care.

\section{Mobile applications for monitoring the menstrual cycle}

The selected mobile applications were compared in relation to the functions offered by manufacturers (Table 1). The table contains 10 functionalities that were considered by the authors as the most important in observing the menstrual cycle:

1. Menstrual cycle, ovulation, and fertility calculator calculation of the days remaining until the onset of menstruation, ovulation and fertile days,

2. Prediction of menstruation - determination of the probable date of the first day of the next menstruation,

3. Notification of upcoming menstruation, ovulation, and fertility - displaying the notification on the main screen of the phone,

4. Cycle tracking - enabling observation of previous cycles,

5. Control of PMS (premenstrual syndrome) - selection and determination of premenstrual syndrome symptoms on a given day,

6. Calculating the chance of getting pregnant on a given day - determining the degree of fertility on a particular day (low, medium, high),

7. Pregnancy mode - adapting the calendar to pregnancy, taking into account the fact of pregnancy,

8. Contraceptive reminder - displaying the notification of contraceptive use on the main screen of the phone,

9. Reminder about breast self-examination - displaying the notification about the need to perform a breast self-examination on a given day on the main screen of the phone,

10. Clear interface - clear graphics, intuitive operation, subdued colors. 
The results of the review: By analyzing the list of applications belonging to the group for monitoring the menstrual cycle, it can be seen that there are many products of low-diversity on the market, offering the same services. Users in their choice can be guided mainly by their preferences as to how to enter data and a sense of aesthetics. The difficulty in finding the right application is the lack of reliable descriptions on the Google Play platform because they are chaotic and carelessly written. It was also noted that the length of time the application is available on the market does not affect its popularity, as it might seem.

\section{Mobile applications for use during pregnancy monitoring}

The selected mobile applications were compared, taking into account the functionalities offered by the manufacturers (Table 2). The table contains 10 functions that were considered by the authors as the most important in monitoring and observing the course of pregnancy.

1. Pregnancy counter - calculates the date of delivery, indicates the current gestational age;
2. Description of the current changes taking place in a mother's body - characterizes the changes occurring in the woman's body during a given period of pregnancy;

3. Description of the current development of the fetus - characterizes the subsequent stages of fetal development, size, and age;

4. Information for the partner - helps the man engage in pregnancy and childbirth by providing tips to help understand the changes occurring in his partner's body;

5. Schedule of medical appointments - enables taking down the date and time of the next visit or suggests a list of tests that a pregnant woman should perform in a given week of pregnancy;

6. Kick counter - allows counting fetal movements;

7. Contraction counter - allows measuring the time and distance between contractions during labor;

8. Weight chart - allows recording the current body weight and creates a chart showing weight gain;

9. List of items to the hospital - list of items necessary for the mother, newborn and partner in the hospital;

10. Clear interface - clear graphics, intuitive operation, subdued colors.

Tab. 1. Mobile applications for monitoring the menstrual cycle

\begin{tabular}{|l|c|c|c|c|c|c|c|c|c|c|c|c|c|}
\hline \multicolumn{1}{|c|}{ Application name / range of functions } & $\mathbf{1}$ & $\mathbf{2}$ & $\mathbf{3}$ & $\mathbf{4}$ & $\mathbf{5}$ & $\mathbf{6}$ & $\mathbf{7}$ & $\mathbf{8}$ & $\mathbf{9}$ & $\mathbf{1 0}$ & $\begin{array}{c}\text { Number of downloads } \\
\text { (year of release) }\end{array}$ & $\begin{array}{c}\text { User } \\
\text { rating }\end{array}$ & $\begin{array}{c}\text { Number of } \\
\text { functions }\end{array}$ \\
\hline Menstruation calendar & + & + & + & + & + & + & + & + & - & + & over 100 million (2012) & $4.8 / 5.0$ & $9 / 10$ \\
\hline Tracking ovulation and menstrual cycle & + & + & + & + & + & + & + & + & - & + & over 1 million (2016) & $4.6 / 5.0$ & $9 / 10$ \\
\hline Tracking menstrual cycle - Ovulation and pregnancy calendar & + & + & + & + & + & + & + & + & - & + & over 5 million (2017) & $4.9 / 5.0$ & $9 / 10$ \\
\hline Flo Menstruation Calendar and Fertile Day Calculator & + & + & + & + & + & + & + & + & - & + & over 10 million (2016) & $4.9 / 5.0$ & $9 / 10$ \\
\hline Femometer - Fertility Tracker & + & + & + & + & + & + & + & + & + & - & over 100 thousand (2018) & $4.7 / 5.0$ & $9 / 10$ \\
\hline Clue Menstrual Calendar: Your period and fertility & + & + & + & + & + & + & - & + & - & + & over 10 million (2014) & $4.8 / 5.0$ & $8 / 10$ \\
\hline Monthly and female ovulation diary. PMS & + & + & + & + & + & + & - & - & - & - & over 50 thousand (2018) & $4.6 / 5.0$ & $6 / 10$ \\
\hline Period Tracker MIA - Ovulation calculator & + & + & + & + & + & + & - & - & - & + & over 1 million (2018) & $4.9 / 5.0$ & $7 / 10$ \\
\hline Period Tracker & + & + & + & + & + & + & + & - & - & - & over 10 million (2011) & $4.5 / 5.0$ & $7 / 10$ \\
\hline Woman Log Calendar & + & + & + & + & + & + & + & + & + & - & over 5 million (2010) & $4.5 / 5.0$ & $9 / 10$ \\
\hline
\end{tabular}

Legend: 1. Menstrual cycle, ovulation, and fertility calculator; 2. Prediction of menstruation; 3. Notification of upcoming menstruation, ovulation, and fertility; 4. Cycle tracking; 5 . Control of PMS symptoms; 6. Calculating the chance of getting pregnant on a given day; 7 . Pregnancy Mode; 8 . Contraceptive reminder 9 . Reminder about breast self-examination; 10 . Clear interface

Tab. 2. Mobile applications helpful during pregnancy monitoring

\begin{tabular}{|l|c|c|c|c|c|c|c|c|c|c|c|c|c|}
\hline \multicolumn{1}{|c|}{ Application name / range of functions } & $\mathbf{1}$ & $\mathbf{2}$ & $\mathbf{3}$ & $\mathbf{4}$ & $\mathbf{5}$ & $\mathbf{6}$ & $\mathbf{7}$ & $\mathbf{8}$ & $\mathbf{9}$ & $\mathbf{1 0}$ & $\begin{array}{c}\text { Number of downloads } \\
\text { (year of release) }\end{array}$ & $\begin{array}{c}\text { User } \\
\text { rating }\end{array}$ & $\begin{array}{c}\text { Number of } \\
\text { functions }\end{array}$ \\
\hline Pregnancy + & + & + & + & + & + & - & - & + & - & + & over 10 million (2016) & $4.6 / 5.0$ & $7 / 10$ \\
\hline Preglife - pregnancy and child & + & + & + & + & + & - & - & + & + & + & over 500 thousand (2011) & $4.7 / 5.0$ & $8 / 10$ \\
\hline Hi Mommy - pregnancy & + & - & + & - & - & - & - & + & + & + & over 100 thousand (2014) & $4.7 / 5.0$ & $5 / 10$ \\
\hline Weekly pregnancy calendar in Polish & + & + & + & - & - & - & + & - & - & + & over 100 thousand (2016) & $4.6 / 5.0$ & $5 / 10$ \\
\hline Pregnancy calculator & + & - & + & - & - & - & - & + & - & - & over 5 thousand (2017) & $3.6 / 5.0$ & $3 / 10$ \\
\hline $\begin{array}{l}\text { My pregnancy with eDziecko.pl - advice and knowledge } \\
\text { in pregnancy }\end{array}$ & + & + & + & - & + & - & - & + & + & + & over 100 thousand(2014) & $4.5 / 5.0$ & $7 / 10$ \\
\hline BabbyApp - pregnancy and childbirth & + & + & + & - & + & + & - & + & - & + & over 50 thousand (2017) & $4.6 / 5.0$ & $7 / 10$ \\
\hline I am pregnant / pregnant App & + & + & + & - & + & + & + & + & + & + & over 1 million (2012) & $4.5 / 5.0$ & $9 / 10$ \\
\hline Pregnancy - Sprout & + & - & + & - & + & + & + & + & + & - & over 1 million (2014) & $4.5 / 5.0$ & $7 / 10$ \\
\hline Baby Chat - pregnancy and childbirth & - & - & - & - & - & - & - & - & - & + & over 10 thousand (2018) & $4.9 / 5.0$ & $\begin{array}{c}\text { Innovative } \\
\text { product }\end{array}$ \\
\hline
\end{tabular}

Legend: 1. Pregnancy counter; 2. Description of the current changes taking place in a mother's body; 3. Description of the current development of the fetus 4 . Information for the partner 5 . Schedule of medical visits; 6. Kicks counter; 7. Contraction counter; 8. Weight chart 9. List of items for the hospital; 10. Clear interface

* This is a completely innovative product enabling pregnant women to ask a qualified midwife, dietitian, or doctor questions (in the premium option). The answers are provided from 9:00 a.m. to 3:00 p.m.

The authors of the application want to take advantage of new technologies and enable reliable online consultation. 
The results of the review: Based on the above list of applications that support pregnancy observation and control, it can be seen that this category is rich and diverse. Users can choose programs according to the functions that interest them most. Medical knowledge is updated on an ongoing basis. However, in many applications, a vast subjectivity can be seen, especially in matters regarding lists of things needed in the hospital or for the newborn. The last application raises concerns to the authors of this article, and makes them wonder whether it is possible to assess the actual state of health via the Internet and give substantive advice that does not put the life and health of mother and child in danger. There is an interesting product available: BABBY CHAT - PREGNANCY AND CHILDBIRTH. It is the highest-rated application on the Google Play platform (4.9 / 5.0 ), it has been downloaded over 10,000 times, and its premiere was in 2018. It is a completely innovative product that enables pregnant women to ask questions directly to a qualified midwife, dietitian or doctor (in the premium option). Answers to questions are provided from 9:00 a.m. to 3:00 p.m. The authors of the application want to take advantage of new technologies and enable reliable online consultation.

\section{Mobile applications used in the prevention of diseases in obstetric and gynecological care}

The selected mobile applications were compared, taking into account the functionalities offered by manufacturers (Table 3). The table contains 7 functions that were considered by the authors as the most important in supporting the prevention and therapy of breast cancer.

1. Information base - presentation of basic information on prevention, therapy, and the course of a neoplastic disease,

2. Breast self-examination reminder - a notification, on the main screen of the phone, about the need for a breast self-examination on a given day,

3. Breast self-examination technique presentation instructions on how to perform a breast self-examination with a description of the basic principles of its proper performance,

4. Possibility to record observed symptoms - a place for notes about own observations concerning the self-examination or the option of marking disturbing symptoms,

5. Screening tests planning - a calendar in which the future screening tests may be recorded and/or tips on their frequency,

6. Scheduling medical appointments - a calendar option that allows for saving the upcoming medical appointments,

7. Clear interface - clear graphics, intuitive operation, subdued colors.

Tab. 3. Mobile applications used in the prevention of diseases in obstetric and gynecological care

\begin{tabular}{|c|c|c|c|c|c|c|c|c|c|c|}
\hline $\begin{array}{l}\text { Application name / } \\
\text { range of functions }\end{array}$ & 1 & 2 & 3 & 4 & 5 & 6 & 7 & Number of downloads (year of release) & User rating & $\begin{array}{l}\text { Number of } \\
\text { functions }\end{array}$ \\
\hline Breast cancer $^{1}$ & + & - & - & - & - & - & - & over 1 million (2017) & $4.2 / 5.0$ & $1 / 7$ \\
\hline Check yourself $^{2}$ & - & + & + & - & - & - & + & over 10 thousand (2018) & $4.4 / 5.0$ & $3 / 7$ \\
\hline My cancer coach app ${ }^{3}$ & + & - & - & + & - & + & + & over 10 thousand (2015) & $4.4 / 5.0$ & $4 / 7$ \\
\hline Breast test $^{4}$ & - & + & + & + & - & + & + & over 10 thousand (2017) & $4.0 / 5.0$ & $5 / 7$ \\
\hline Breast Researchers ${ }^{5}$ & + & + & + & - & - & - & + & over 10 thousand (2014) & $4.0 / 5.0$ & $4 / 7$ \\
\hline Braster Care $^{6}$ & - & - & - & - & - & - & + & Over 1 thousand (2016) & $4.5 / 5.0$ & $1 / 7$ \\
\hline Know your lemons ${ }^{7}$ & + & + & + & + & + & + & + & Over 1 thousand (2018) & $4.0 / 5.0$ & $7 / 7$ \\
\hline Breast cancer ${ }^{1}$ & \multicolumn{10}{|c|}{$\begin{array}{l}\text { English language version. The creators offer extensive notes on how to prevent cancer, } \\
\text { as well as educational videos with the participation of Dr. Marisa Weiss - oncologist, talking about prevention and the disease itself. }\end{array}$} \\
\hline Check yourself ${ }^{2}$ & \multicolumn{10}{|c|}{$\begin{array}{l}\text { English language version. When starting the application, the user is asked whether they want to start with "Presentation of the breast } \\
\text { self-examination technique" (function no. 3) or set the option "Reminder about breast self-examination" (function no. 2), } \\
\text { which allows you to select the day and hours of receipt of the notification. }\end{array}$} \\
\hline My cancer coach app 3 & \multicolumn{10}{|c|}{$\begin{array}{l}\text { English language version. It is one of the most popular applications supporting the therapy of cancer. It enables tracking of treatment } \\
\text { for patients suffering not only from breast cancer but also from colorectal or prostate cancer. It does not respond to the need for monthly } \\
\text { breast self-examination or self-examination instructions. }\end{array}$} \\
\hline Breast test ${ }^{4}$ & \multicolumn{10}{|c|}{$\begin{array}{l}\text { Many language versions. It lacks "Information Base" (function 1) because the application only offers limited information on what symptoms } \\
\text { and changes should worry the user during the examination, and does not contain information on prevention or breast cancer itself, } \\
\text { as well as "Planning screening tests"(function no. 5). }\end{array}$} \\
\hline Breast Researchers ${ }^{5}$ & \multicolumn{10}{|c|}{$\begin{array}{l}\text { Polish language version. It has an "Information Base" (function No. 1), which contains interesting facts about breast cancer, self-examination } \\
\text { or breasts themselves, divided into tabs corresponding to individual age groups of users. It also has a "Reminder for breast self-examination" } \\
\text { (function no. 2), which refers to the data we have entered regarding menstruation. "Presentation of the breast self-examination technique" } \\
\text { (function no. 3) is demonstrated by well-known male figures in Poland, such as Tomasz Ciachorowski or Rafał Brzozowski, who, during the video, } \\
\text { perform the entire test step by step to facilitate its self-implementation on their example. The whole is provided with a "Clear interface." }\end{array}$} \\
\hline Braster Care ${ }^{6}$ & \multicolumn{10}{|c|}{$\begin{array}{l}\text { It comes in many language versions. It functions as a complementary product for the paid Braster device, allowing for independent } \\
\text { breast examination at home. It does not fully meet the requirements for functionality presented in the table, but its innovation deserves } \\
\text { to be presented in the list of the most popular applications supporting breast cancer prevention. }\end{array}$} \\
\hline Know your lemons ${ }^{7}$ & \multicolumn{10}{|c|}{$\begin{array}{l}\text { English language version. The application fulfills all the functions shown in the table. The product informs about the standard test plan } \\
\text { together with the description, and for users from the United States, there is a possibility to sign up for mammography using the application. } \\
\text { Each activity can be provided with a reminder. The graphic design meets the expectations of function no. } 7 \text { - "Clear interface", however, } \\
\text { the colors are too bright and make it difficult to use the program. }\end{array}$} \\
\hline
\end{tabular}

Legend: 1 . Information base; 2 . Reminder about breast self-examination; 3 . Presentation of the breast self-examination technique; 4 . Option to save observed symptoms; 5 . Planning screening tests; 6. Planning medical visits; 7. Clear interface. 
The results of the review: Based on the above list of applications supporting the prevention and therapy of breast cancer, it can be seen that the presented category of medical applications is the most diverse, due to the scope of content and health control proposals, while a deficit of many functions in individual applications is visible. The relatively small number of downloads in relation to the product release date indicates the low interest of potential recipients or insufficiently developed advertising. The most popular application is the one that includes in its resources materials from a reliable, medical source, presented by an oncologist. It can, therefore, be assumed that this implementation of the topic inspires confidence in users and encourages using the product.

\section{DISCUSSION}

The technology, that has been developing in recent years, has significantly influenced the availability of information in every area of life. The mobile application market in Poland is also constantly developing. According to the report of the Polityka Insight analysis center, as early as 2015, Poles had almost 19 million smartphones. Mobile applications related to health and sport constituted the sixth-largest group among all the applications downloaded to mobile phones [9]. Therefore, for women who can use them, it is an easy tool to find answers to the questions bothering them - from searching for recipes, through the possibility of observing your body and fertility, to diagnosing rare cases.

The World Health Organization (WHO) in its publication on the impact of e-Health on improving the quality of medical care in developing countries, indicates telecommunications as an invaluable tool, helping to reach as many patients as possible. Raising health awareness in Bangladesh through an SMS campaign enables patients to obtain health information that they can access via mobile phones. For example, pregnant women in remote villages can register their mobile phone numbers to receive useful prenatal advice appropriate for the stage of pregnancy [10]. The frequency of using the Internet as a source of medical information is constantly increasing, which is largely influenced by insufficient attention to patients and providing only routine information at the beginning of pregnancy, when women have the largest number of questions, as Kraschnewski and others stated in their study [11].

In a study conducted among Italian citizens by Bert and others [12], almost all women under observation (95\%) turned out to use the Internet as a source of medical information, some of whom also gained knowledge from professionals. The main reason for using the Internet to search for medical knowledge was the need to deepen knowledge on pregnancy-related topics [12]. At the same time, the topic of pregnancy is one of the most frequently searched on the Internet by female and male respondents, as confirmed by a study conducted by Liam-Pereria, saying that $97.7 \%$ of Internet users searched for any information about it, and $26.9 \%$ of them did this within 24 hours back [13]. In contrast, studies conducted by
Stephanie Wallwiener and others [14] on a group of 220 pregnant women making use of medical services in two university hospitals in Germany have shown that $50.8 \%$ of the women surveyed use the Internet to search for information on the proper course of pregnancy, delivery and postpartum, while $22.4 \%$ of respondents use only applications for this purpose and $16.2 \%$ use both of these sources. At the same time, it was concluded that women using pregnancy applications are younger and the impact of the information they seek is significant [14]. Subsequent studies in China have shown that the majority of women $(81.5 \%)$ search for information in these sources at the beginning of pregnancy [15], which coincides with studies conducted in Italy. Those pregnant respondents most often seek answers to the questions bothering them in the first trimester of pregnancy [16].

There is a lack of research in Poland regarding the use of mobile applications by pregnant women. However, the fact that the wide selection and dissemination of medical applications for women of all ages affects cooperation between women and midwives cannot be underestimated. The midwife as a health care worker who works closest to women has a decisive impact on pre-concept, prenatal and menopause education. The Internet and mobile programs play a significant supporting and complementary role in providing information by midwives. A handy form of access to knowledge equips midwives with functional tools, thanks to which health education is continuous. The fact that patients use medical applications to monitor their health increases the accuracy of recording the date and time of the occurrence of the specific symptoms so that they can be associated with specific disorders during the diagnosis of pathology. Family midwives, aware of the use of medical applications by a woman, can trust her in the matter of self-control. Also, the functions offered by the applications streamline the delivery of health education in an accessible and convenient way. The messages about the possible symptoms in a given period, displayed on an ongoing basis, also reduce the patient's exposure to unnecessary stress, which allows midwives to focus on disturbing symptoms, rather than dispel the patient's doubts. Thanks to easily accessible and legible tips on breast self-examination, which complement and recall information obtained in the context of health education, midwives have the opportunity to leave health control in the hands of women. The success of awareness-raising activities is greater when messages highlighting irregularities are at the patient's fingertips.

Interest in applications and the Internet has a great impact on women and continues to grow. However, these sources are still often not very reliable. In a study conducted by Rezniczka and others, only $4.2 \%$ of German pages regarding gynecological problems can be assessed as decent [17], and the study conducted by Bert and others states that only half of the most popular pregnancy applications give the source of information they contain [18].

The use of mobile applications as a tool for obtaining health information by women is a relatively new phenomenon. However, a significant impact on women's health can already be seen. Therefore, for the purpose of 
this work, a review of the functions offered by the most popular applications for monitoring the menstrual cycle and pregnancy, and prevention of breast cancer available on the Google Play platform was carried out. These are applications that allow to control changes that occur in the female body and contain tips on how to deal with pathologies.

\section{CONCLUSIONS}

In the group of the analyzed mobile applications that help control the menstrual cycle, as much as $83 \%$ have a range of functions offered by manufacturers and facilitating independent control by women. Lower function indicators (63\%) occur in the group of applications helpful in monitoring pregnancy and even lower in the group of disease prevention. Mobile health applications are a promising strategy for health education as a tool for monitoring, improving self-control and raising awareness in the care of women, though the lack of formal regulations regarding the confirmation of the credibility of available health applications indicates the need for increased vigilance by women and health care professionals.

\section{Aplikacje mobilne w edukacji zdrowotnej kobiet w opiece położniczo-ginekologicznej}

\section{WPROWADZENIE}

Dynamiczny rozwój nowych technologii i upowszechnienie aplikacji mobilnych w życiu codziennym, stwarzają możliwości wykorzystywania nowej formy do działań w ramach edukacji zdrowotnej pacjentów, w tym także grupy o szczególnych potrzebach edukacyjnych tj. kobiet. Aplikacje mobilne jako oprogramowanie działające na urządzeniach przenośnych (smartfony, tablety itp.) znajdują szczególne uznanie w grupie osób młodszych, a także dorosłych. Urządzenia ułatwiają, ale także zmieniają sposób komunikacji, wpływają na podejmowane decyzje oraz znacząco poprawiają jakość życia [1]. Stają się również szczególną formą komunikacji dla potrzeb edukacji zdrowotnej. Ich atrakcyjność i łatwość stosowania powodują ogromny wzrost zainteresowania i szerokie użycie wspierające wszystkie aspekty życia, także zagadnienia z zakresu edukacji zdrowotnej [2].

Mobilne zdrowie (m-zdrowie) to nowy i szybko rozwijający się obszar odgrywający istotną rolę w przemianach opieki zdrowotnej, który może mieć znaczenie dla jakości i wydajności usług medycznych oraz edukacyjnych dla pacjentów. Rynek aplikacji mobilnych w opiece zdrowotnej rozwija się intensywnie. Aktualnie największa liczba aplikacji mobilnych dotyczy pro-zdrowotnej aktywności fizycznej (31\%), programów z informacjami medycznymi (około 17\%) i tzw. wellness -aplikacje relaksacyjne (ponad 15\%), aplikacji żywieniowych (7\%) czy programów zarządzania stanem zdrowia (7\%). W grupie aplikacji m-zdrowie znajdują się także adresowane do konkretnych grup pacjentów np. z cukrzycą i innymi chorobami przewlekłymi, przestrzegania zaleceń terapeutycznych czy udzielania pierwszej pomocy [3].

W 2017 r. ponad 325000 aplikacji zdrowotnych i medycznych było dostępnych w Google Play Store i Apple AppStore [4].

Większość aplikacji z dziedziny mHealth dotyczy poprawy ogólnej kondycji zdrowotnej. Jednak liczba aplikacji do zarządzania stanem zdrowia i diagnostyki chorób szybko rośnie, stanowiąc obecnie $40 \%$ wszystkich aplikacji związanych ze zdrowiem. W roku 2017 aplikacje mobilne obejmujące zakresem tematycznym zdrowie kobiet i ciąża stanowiły 9\% [5].

Nowatorskie systemy m-zdrowia nie są jednak pozbawione niedoskonałości i zagrożeń. Atrakcyjna forma i zakres treści aplikacji m-Health łączy się z obawami co do bezpieczeństwa takich rozwiązań oraz samodzielnością pacjenta w podejmowaniu decyzji, które mogą być błędne lub nieaktualne [6]. Bezpieczeństwo danych jest również głównym problemem wśród specjalistów zajmujących się zdrowiem, gdy polecają klientom aplikacje mobilne [7].

Niestety brak jest klarownych przepisów określających, które aplikacje i w jakim stopniu powinny podlegać kontroli zanim trafią na rynek użytkownika. W niewielkim stopniu wątpliwości można zweryfikować przeglądając Europejski Katalog Aplikacji Zdrowotnych (European Directry of Health Apps), który gromadzi i archiwizuje informacje o wiarygodnych aplikacjach zdrowotnych [8].

\section{CEL}

Celem pracy jest przegląd wybranych aplikacji mobilnych dostępnych do wykorzystywania w edukacji zdrowotnej kobiet w opiece położniczo-ginekologicznej oraz określenie ich zakresu funkcji ułatwiających samodzielną kontrolę stanu zdrowia przez kobiety.

\section{MATERIAŁ I METODA}

W badaniach aplikacji mobilnych ograniczono się do aplikacji dostępnych dla systemu Android oraz systemu iOS (iPhone). W Polsce głównymi źródłami pozyskiwania mobilnych aplikacji medycznych są Sklep Google Play oraz AppStore. Źródłem wszystkich informacji są strony producentów danego oprogramowania. Kryterium włączenia aplikacji do analizy było: aplikacja dostępna na stronie internetowej play. google.com oraz aplikacja przydatna w opiece położniczo-ginekologicznej kobiet. Spośród dostępnych na rynku do analiz włączono 27 aplikacji, które miały największą liczbę pobrań. 


\section{WYNIKI}

Ze względu na zakres merytoryczny edukacji zdrowotnej kobiet dokonano klasyfikacji aplikacji mobilnych na trzy grupy: 1) kontrola cyklu miesiączkowego, 2) monitorowanie ciąży, 3) profilaktyka chorób w opiece ginekologiczno- położniczej. Spośród wszystkich dostępnych aplikacji wybrano 10 stosowanych w kontroli cyklu miesiączkowego, 10 do zastosowania w trakcie monitorowania ciąży oraz 7 wykorzystywanych w profilaktyce chorób w opiece ginekologiczno - położniczej.

\section{Aplikacje mobilne służące do monitorowania cyklu miesiączkowego}

Wybrane aplikacje mobilne zostały porównane względem funkcji oferowanych przez producentów (Tabela 1). W tabeli znalazło się 10 funkcji, które zostały uznane przez autorów jako najistotniejsze w obserwacji cyklu miesiączkowego:

1. Kalkulator cyklu menstruacyjnego, owulacji i płodności - obliczanie dni pozostałych do pojawienia się miesiączki, owulacji i dni płodnych.
2. Przewidywanie menstruacji - określenie prawdopodobnej daty pierwszego dnia najbliższej menstruacji.

3. Powiadomienie o zbliżającej się menstruacji, owulacji i płodności - wyświetlenie powiadomienia na ekranie głównym telefonu.

4. Śledzenie cyklu - umożliwienie obserwacji poprzednich cykli.

5. Kontrola objawów PMS (premenstrual syndrome) wybór i oznaczenie objawów zespołu napięcia przedmiesiączkowego występujących danego dnia.

6. Obliczenie szansy na zajście w ciążę w danym dniu określenie stopnia płodności w danym dniu (niska, średnia, wysoka).

7. Tryb ciąży - uwzględnienie faktu zajścia w ciążę i dostosowanie kalendarza do prowadzenia ciąży.

8. Przypomnienie o antykoncepcji - wyświetlenie powiadomienia o zastosowaniu antykoncepcji na ekranie głównym telefonu.

9. Przypomnienie o samobadaniu piersi - wyświetlenie powiadomienia o konieczności wykonania samobadania piersi w danym dniu na ekranie głównym telefonu.

10. Przejrzysty interfejs - czytelna grafika, intuicyjna obsługa, stonowana kolorystyka.

Tab. 1. Aplikacje mobilne służące do monitorowania cyklu miesiączkowego

\begin{tabular}{|l|c|c|c|c|c|c|c|c|c|c|c|c|c|}
\hline \multicolumn{1}{|c|}{ Nazwa aplikacji/zakres funkcji } & $\mathbf{1}$ & $\mathbf{2}$ & $\mathbf{3}$ & $\mathbf{4}$ & $\mathbf{5}$ & $\mathbf{6}$ & $\mathbf{7}$ & $\mathbf{8}$ & $\mathbf{9}$ & $\mathbf{1 0}$ & $\begin{array}{c}\text { Liczba pobrań } \\
\text { (rok prdukcji) }\end{array}$ & $\begin{array}{c}\text { Ocena } \\
\text { użytkowników }\end{array}$ & $\begin{array}{c}\text { Liczba } \\
\text { funkcji }\end{array}$ \\
\hline Kalendarz miesiączka & + & + & + & + & + & + & + & + & - & + & ponad 100 milionów (2012) & $4,8 / 5,0$ & $9 / 10$ \\
\hline Śledzenie owulacji i okresu & + & + & + & + & + & + & + & + & - & + & ponad milion (2016) & $4,6 / 5,0$ & $9 / 10$ \\
\hline Śledzenie okresu- Kalendarz owulacji i ciąży & + & + & + & + & + & + & + & + & - & + & ponad 5 milionów (2017) & $4,9 / 5.0$ & $9 / 10$ \\
\hline Kalendarz Miesiączka Flo i Kalkulator Dni Płodnych & + & + & + & + & + & + & + & + & - & + & ponad 10 milionów (2016) & $4,9 / 5.0$ & $9 / 10$ \\
\hline Femometr- FertilityTracker & + & + & + & + & + & + & + & + & + & - & ponad100 tysięcy razy (2018) & $4,7 / 5.0$ & $9 / 10$ \\
\hline Kalendarz Miesiączkowy Clue: Twój okres i płodność & + & + & + & + & + & + & - & + & - & + & ponad10 milionów (2014) & $4.8 / 5.0$ & $8 / 10$ \\
\hline Miesięczny i żeński pamiętnik owulacji, PMS & + & + & + & + & + & + & - & - & - & - & ponad50 tysięcy (2018) & $4,6 / 5.0$ & $6 / 10$ \\
\hline Period Tracker MIA- Ovulationcalculator & + & + & + & + & + & + & - & - & - & + & ponad milion (2018) & $4,9 / 5.0$ & $7 / 10$ \\
\hline Period Tracker & + & + & + & + & + & + & + & - & - & - & ponad 10 milionów (2011) & $4,5 / 5.0$ & $7 / 10$ \\
\hline WomanLog Kalendarz & + & + & + & + & + & + & + & + & + & - & ponad 5 milionów (2010) & $4,5 / 5.0$ & $9 / 10$ \\
\hline
\end{tabular}

Legenda: 1. Kalkulator cyklu menstruacyjnego, owulacji i płodności; 2. Przewidywanie menstruacji ;3. Powiadomienie o zbliżającej się menstruacji, owulacji i płodności; 4. Śledzenie cyklu ; 5 . Kontrola objawów PMS; 6. Obliczenie szansy na zajście w ciążę w danym dniu; 7. Tryb ciąży ; 8. Przypomnienie 0 antykoncepcji 9. Przypomnienie o samobadaniu piersi; 10. Przejrzysty interfejs

Tab. 2. Aplikacje mobilne pomocne w trakcie monitorowania ciąży

\begin{tabular}{|l|c|c|c|c|c|c|c|c|c|c|c|c|c|}
\hline \multicolumn{1}{|c|}{ Nazwa aplikacji/zakres funkcji } & $\mathbf{1}$ & $\mathbf{2}$ & $\mathbf{3}$ & $\mathbf{4}$ & $\mathbf{5}$ & $\mathbf{6}$ & $\mathbf{7}$ & $\mathbf{8}$ & $\mathbf{9}$ & $\mathbf{1 0}$ & $\begin{array}{c}\text { Liczba pobrań } \\
\text { (rok produkcji) }\end{array}$ & $\begin{array}{c}\text { 0cena } \\
\text { użytkowników }\end{array}$ & $\begin{array}{c}\text { Liczba } \\
\text { funkcji }\end{array}$ \\
\hline Ciąża + & + & + & + & + & + & - & - & + & - & + & ponad 10 milionów (2016) & $4,6 / 5.0$ & $7 / 10$ \\
\hline Preglife- ciąża i dziecko & + & + & + & + & + & - & - & + & + & + & ponad 500 tysięcy (2011) & $4,7 / 5.0$ & $8 / 10$ \\
\hline HiMommy- ciąża & + & - & + & - & - & - & - & + & + & + & ponad 100 tysięcy (2014) & $4,7 / 5.0$ & $5 / 10$ \\
\hline Kalendarz ciążowy tydzień po tygodniu po polsku & + & + & + & - & - & - & + & - & - & + & ponad 100 tysięcy (2016) & $4,6 / 5.0$ & $5 / 10$ \\
\hline Kalkulator ciążowy & + & - & + & - & - & - & - & + & - & - & ponad 5 tysięcy (2017) & $3,6 / 5,0$ & $3 / 10$ \\
\hline Moja ciąża z eDziecko.pl- porady i wiedza w ciąży & + & + & + & - & + & - & - & + & + & + & ponad 100 tysięcy (2014) & $4,5 / 5.0$ & $7 / 10$ \\
\hline BabbyApp- ciąża i poród & + & + & + & - & + & + & - & + & - & + & ponad 50 tysięcy (2017) & $4,6 / 5.0$ & $7 / 10$ \\
\hline Jestem w ciąży / ciążza App & + & + & + & - & + & + & + & + & + & + & ponad milion (2012) & $4,5 / 5.0$ & $9 / 10$ \\
\hline Ciążz-Sprout & + & - & + & - & + & + & + & + & + & - & ponad milion (2014) & $4,5 / 5.0$ & $7 / 10$ \\
\hline Baby Chat- ciąża i poród & - & - & - & - & - & - & - & - & - & + & ponad 10 tysięcy (2018) & $4,9 / 5,0$ & $\begin{array}{c}\text { innowacyjny } \\
\text { produkt* }\end{array}$ \\
\hline
\end{tabular}

Legenda: 1. Licznik trwania ciąży; 2. Opis aktualnych zmian zachodzących u matki; 3. Opis aktualnego rozwoju płodu 4. Informacje dla partnera 5. Terminarz wizyt lekarskich; 6. Licznik kopnięć; 7. Licznik skurczy; 8. Wykres wagi 9. Lista rzeczy do szpitala; 10. Przejrzysty interfejs

* Jest to całkowicie innowacyjny produkt umożliwiający ciężarnym zadawanie pytań bezpośrednio do wykwalifikowanej położnej, dietetyka lub lekarza (w opcji premium). Odpowiedzi na pytania są udzielane w godzinach od 9 do 15. Autorzy aplikacji pragną wyjść naprzeciw nowym technologiom i umożliwić rzetelne konsultacje on-line. 
Wyniki przeglądu: Analizując zestawienie aplikacji z grupy do monitorowania cyklu miesiączkowego zauważyć można, że na rynku funkcjonuje wiele produktów o małej różnorodności oferujących te same usługi. Użytkowniczki w swoim wyborze mogą kierować się głównie upodobaniami co do sposobu wprowadzania danych i poczuciem estetyki. Utrudnieniem w poszukiwaniu odpowiedniej aplikacji jest brak rzetelnych opisów znajdujących się na platformie Google Play, ponieważ są one chaotyczne i niedbałe. Zauważono także, że długość czasokresu dostępności aplikacji na rynku nie wpływa na jej popularność jak mogłoby się wydawać.

\section{Aplikacje mobilne do wykorzystania w trakcie monitorowania ciąży}

Wybrane aplikacje mobilne zostały porównane względem funkcji oferowanych przez producentów (Tabela 2). W tabeli znalazło się 10 funkcji, które zostały uznane przez autorów jako najistotniejsze w kontroli i obserwacji przebiegu ciąży.

1. Licznik trwania ciąży- oblicza termin porodu, wskazuje aktualny wiek ciążowy.

2. Opis aktualnych zmian zachodzących u matki- charakteryzuje zmiany zachodzące w ciele kobiety w danym okresie trwania ciąży.
3. Opis aktualnego rozwoju płodu-charakteryzuje kolejne etapy rozwoju płodu, wielkość i wiek.

4. Informacje dla partnera- pomaga mężczyźnie zaangażować się w ciąże i poród udzielając wskazówek ułatwiających zrozumienie zmian zachodzących w organizmie partnerki.

5. Terminarz wizyt lekarskich- umożliwia zanotowanie daty i godziny kolejnej wizyty lub proponuje listę badań, które ciężarna powinna wykonać w danym tygodniu ciąży;

6. Licznik kopnięć- umożliwia liczenie ruchów płodu.

7. Licznik skurczy- umożliwia mierzenie czasu i odległości między skurczami w czasie porodu.

8. Wykres wagi- umożliwia notowanie aktualnej masy ciała i sporządza wykres pokazujący przyrostu.

9. Lista rzeczy do szpitala- lista przedmiotów niezbędnych w szpitalu dla matki, noworodka i partnera.

10. Przejrzysty interfejs-czytelna grafika, intuicyjna obsługa, stonowana kolorystyka.

Wyniki przeglądu:W oparciu o powyższe zestawienie aplikacji wspomagających obserwację i kontrolę ciąży, można zauważyć, że jest to kategoria bogata i różnorodna. Użytkowniczki mogą wybierać aplikacje według najbardziej interesujących je funkcji. Wiedza medyczna jest na bieżąco aktualizowana, jednak w wielu aplikacjach,

Tab. 3. Aplikacje mobilne wykorzystywane w profilaktyce chorób w opiece ginekologiczno-położniczej

\begin{tabular}{|c|c|c|c|c|c|c|c|c|c|c|}
\hline $\begin{array}{l}\text { Nazwa aplikacji/ } \\
\text { zakres funkcji }\end{array}$ & 1 & 2 & 3 & 4 & 5 & 6 & 7 & Liczba pobrań (rokprodukcji) & $\begin{array}{c}\text { Ocena } \\
\text { użytkowników }\end{array}$ & $\begin{array}{l}\text { Liczba } \\
\text { funkcji }\end{array}$ \\
\hline Rak piersi ${ }^{1}$ & + & - & - & - & - & - & - & ponad million (2017) & $4,2 / 5,0$ & $1 / 7$ \\
\hline Check yourself ${ }^{2}$ & - & + & + & - & - & - & + & ponad 10 tysięcy (2018) & $4,4 / 5,0$ & $3 / 7$ \\
\hline My cancer coach app ${ }^{3}$ & + & - & - & + & - & + & + & ponad10 tysięcy (2015) & $4,4 / 5,0$ & $4 / 7$ \\
\hline Breast test $^{4}$ & - & + & + & + & - & + & + & ponad 10 tysięcy (2017) & $4,0 / 5,0$ & $5 / 7$ \\
\hline PiersiBadacze ${ }^{5}$ & + & + & + & - & - & - & + & ponad 10 tysięcy (2014) & $4,0 / 5,0$ & $4 / 7$ \\
\hline Braster Care $^{6}$ & - & - & - & - & - & - & + & ponad tysią crazy (2016) & $4,5 / 5,0$ & $1 / 7$ \\
\hline Know your lemons ${ }^{7}$ & + & + & + & + & + & + & + & ponad tysią crazy (2018) & $4,0 / 5,0$ & $7 / 7$ \\
\hline Rak piersi & \multicolumn{10}{|c|}{$\begin{array}{l}\text { Angielska wersja językowa. Twórcy oferują obszerne notatki dotyczące sposobów zapobiegania nowotworowi, a także edukacyjne filmy video } \\
\text { z udziałem dr Marisy Weiss - lekarza onkologa, mówiące o profilaktyce jak i samej chorobie. }\end{array}$} \\
\hline Check yourself ${ }^{2}$ & \multicolumn{10}{|c|}{$\begin{array}{l}\text { Angielska wersja językowa. Przy uruchomieniu aplikacji, przed użytkownikiem stawiany jest wybór, czy chce on zacząć od „Przedstawienia } \\
\text { techniki samobadania piersi” (funkcja nr 3) czy ustawienia samej opcji „Przypomnienie o samobadaniu piersi” (funkcja nr 2), która pozwala } \\
\text { na wybranie w kalendarzu dnia i godziny otrzymania powiadomienia }\end{array}$} \\
\hline My cancer coach app 3 & \multicolumn{10}{|c|}{$\begin{array}{c}\text { Angielska wersja językowa. Stanowi jedną z najpopularniejszych aplikacji wspomagających terapię choroby nowotworowej. Umożliwia śledzenie } \\
\text { leczenia pacjentom cierpiącym nie tylko na raka piersi, ale także na raka jelita grubego czy prostaty. Nie odpowiada na potrzebę comiesięcznego } \\
\text { samobadania piersi czy podręcznego instruktażu samobadania. }\end{array}$} \\
\hline Breast test $^{4}$ & \multicolumn{10}{|c|}{$\begin{array}{l}\text { Wiele wersji językowych. Brak jej „Bazy informacyjnej” (funkcja nr 1), ponieważ aplikacja oferuje jedynie okrojone informacje na temat tego, } \\
\text { jakie zauważone objawy i zmiany powinny niepokoić w trakcie badania, ponadto nie zawiera informacji na temat profilaktyki czy samego raka } \\
\text { piersi, a także „Planowania badań przesiewowych” (funkcja nr 5). }\end{array}$} \\
\hline PiersiBadacze 5 & \multicolumn{10}{|c|}{$\begin{array}{l}\text { Polska wersja językowa.Posiada „Bazę informacyjną" (funkcja nr 1), w której zawarte są fakty, ciekawostki dotyczące raka piersi, samobadania czy samych } \\
\text { piersi, podzielone na zakładki odpowiadające poszczególnym grupom wiekowym użytkowniczek. Posiada również,_Przypomnienie o samobadaniu piersi” } \\
\text { (funkcja nr 2), które odnosi się do wprowadzonych przez nas danych dotyczących menstruacji.,_Przedstawienie techniki samobadania piersi” (funkcja } \\
\text { nr 3) przedstawiona jest przez znane męskie w Polsce postacie, jak np. Tomasz Ciachorowski czy Rafał Brzozowski, którzy w trakcie filmiku krok po kroku } \\
\text { wykonują całe badanie, aby ułatwić samodzielne jego wykonanie na ich przykładzie. Całość opatrzona jest w „Przejrzysty interfejs” }\end{array}$} \\
\hline Braster Care $^{6}$ & \multicolumn{10}{|c|}{$\begin{array}{l}\text { Występuje w wielu wersjach językowych. Funkcjonuje jako produkt uzupełniający dla płatnego urządzenia Braster, pozwalającego na } \\
\text { samodzielne badanie piersi w domu. Nie wpisuje się w pełni w wymagania związane z funkcjonalnością przedstawione w tabeli, jednak jej } \\
\text { innowacyjność zasługuje na przedstawienie w zestawieniu najpopularniejszych aplikacji wspomagających profilaktykę raka piersi }\end{array}$} \\
\hline Know your lemons ${ }^{7}$ & \multicolumn{10}{|c|}{$\begin{array}{l}\text { Angielska wersja językowa. Aplikacja spełnia wszystkie funkcja z ukazanych w tabeli. Produkt informuje o wzorcowym planie badań } \\
\text { wraz z opisem, a dla użytkowniczek pochodzących ze Stanów Zjednoczonych przewidziano możliwość zapisania się na mammografię za pomocą } \\
\text { aplikacji. Każda z aktywności może zostać opatrzona przypomnieniem. Opracowanie graficzne spełnia oczekiwania związane z funkcją nr } 7 \text { - } \\
\text { "Przejrzysty interfejs", jednak zastosowana kolorystyka jest zbyt jaskrawa i utrudnia korzystanie z programu. }\end{array}$} \\
\hline
\end{tabular}

Legenda: 1 .Baza informacyjna; 2. Przypomnienie o samobadaniu piersi; 3. Przedstawienie techniki samobadania piersi; 4. Możliwość zapisania zaobserwowanych objawów; 5. Planowanie badań przesiewowych; 6. Planowanie wizyt lekarskich; 7. Przejrzysty interfejs. 
zwłaszcza w częściach dotyczących list rzeczy potrzebnych do szpitala lub noworodka, można dostrzec duży subiektywizm. Obawy autorek artykułu budzi też ostatnia aplikacja, oraz zastanawia fakt czy przez internet można ocenić rzeczywisty stan zdrowia i udzielić merytorycznej porady nie zagrażającej życiu lub zdrowiu matki i dziecka. Interesującym produktem dostępnym jest aplikacja BABBY CHAT- CIĄŻA I PORÓD. Jest to najwyżej oceniana aplikacja znajdująca się na platformie Google Play 4,9/5,0, pobrano ją ponad 10 tysięcy razy, a swoją premierę miała w 2018 roku. Jest to całkowicie innowacyjny produkt umożliwiający ciężarnym zadawanie pytań bezpośrednio do wykwalifikowanej położnej, dietetyka lub lekarza (w opcji premium). Odpowiedzi na pytania są udzielane w godzinach od 9 do 15. Autorzy aplikacji pragną wyjść naprzeciw nowym technologiom i umożliwić rzetelne konsultacje on-line.

\section{Aplikacje mobilne wykorzystywane w profilaktyce chorób w opiece ginekologiczno- położniczej}

Wybrane aplikacje mobilne zostały porównane względem funkcji oferowanych przez producentów (Tabela 3). W tabeli znalazło się 7 funkcji, które zostały uznane przez autorów jako najistotniejsze we wspomaganiu profilaktyki i terapii raka piersi.

1. Baza informacyjna - przedstawienie podstawowych informacji na temat profilaktyki, terapii i przebiegu choroby nowotworowej

2. Przypomnienie o samobadaniu piersi - wyświetlenie powiadomienia o konieczności wykonania samobadania piersi w danym dniu na ekranie głównym telefonu

3. Przedstawienie techniki samobadania piersi - instruktaż wykonania samobadania piersi opatrzony opisem podstawowych zasad jego prawidłowego wykonania

4. Możliwość zapisania zaobserwowanych objawów miejsce na notatki dotyczące własnych spostrzeżeń w odniesieniu do przeprowadzonego samobadania lub opcja oznaczenia niepokojących objawów

5. Planowanie badań przesiewowych - kalendarz dedykowany zapisaniu przyszłych badań przesiewowych i/lub wskazówki dotyczące częstotliwości ich wykonywania

6. Planowanie wizyt lekarskich - opcja kalendarza umożliwiająca zapisanie zbliżających się wizyt lekarskich

7. Przejrzysty interfejs - czytelna grafika, intuicyjna obsługa, stonowanakolorystyka

Wyniki przeglądu: W oparciu o powyższe zestawienie aplikacji wspomagających profilaktykę i terapię raka piersi zauważyć można, iż przedstawiona kategoria aplikacji medycznych jest najbardziej zróżnicowana ze względu na zakres treści oraz propozycji kontroli stanu zdrowia, a jednocześnie widoczny jest deficyt wielu funkcji w poszczególnych aplikacjach. Stosunkowo mała liczba pobrań w odniesieniu do daty premiery produktu wskazuje na małe zainteresowanie potencjalnych odbiorców lub niedostatecznie rozwiniętą reklamę. Aplikacją cieszącą się największą popularnością jest aplikacja posiadająca $\mathrm{w}$ swoich zasobach materiały pochodzące $\mathrm{z}$ wiarygodnego, medycznego źródła, prezentowanego przez lekarza onkologa. Można więc założyć, iż taka realizacja tematu wzbudza w użytkownikach zaufanie i zachęca do skorzystania $\mathrm{z}$ produktu.

\section{DYSKUSJA}

Rozwijająca się w ostatnich latach technologia znacząco wpłynęła na dostępność informacji dotyczących każdej dziedziny życia. Rynek aplikacji mobilnych w Polsce także ulega ciągłemu rozwojowi. Jak podaje raport centrum analiz Polityka Insight, już w 2015roku, Polacy posiadali prawie $19 \mathrm{mln}$ smatrfonów. Mobilne aplikacje związane ze zdrowiem i sportem stanowiły szóstą co do wielkości grupę wśród wszystkich [pobieranych na telefony komórkowe aplikacji [9]. Dlatego też, dla kobiet potrafiących z niej korzystać jest łatwym narzędziem do wyszukania odpowiedzi na nurtujące je pytania - od wyszukiwania przepisów kulinarnych, przez możliwość obserwacji swojego ciała i płodności, do diagnozowania rzadkich przypadków chorobowych.

Światowa Organizacja Zdrowia (WHO) w swojej publikacji na temat wpływu e-Zdrowia na poprawę jakości opieki medycznej w krajach rozwijających się, wskazuje telekomunikację jako nieocenione narzędzie, wspomagające dotarcie do jak największej ilości pacjentów. Podnoszenie świadomości zdrowotnej w Bangladeszu za pośrednictwem kampanii SMS umożliwia zdobycie przez pacjentów informacji zdrowotnych, do których mogą uzyskać dostęp za pośrednictwem telefonów komórkowych. Na przykład kobiety w ciąży w odległych wioskach mogą rejestrować swoje numery komórkowe, aby otrzymywać przydatne porady prenatalne, odpowiednie do etapu ciąży [10]. Częstotliwość wykorzystywania Internetu, jako źródła informacji medycznych, stale rośnie, na co wpływ w zdecydowanej mierze ma niedostateczne poświęcenie uwagi pacjentkom oraz przekazywanie mu tylko rutynowych informacji na początku ciąży, kiedy kobiety mają najwięcej pytań, co w swoim badaniu stwierdził Kraschnewski i inni.[11]

W badaniu przeprowadzonym wśród obywatelek Włoch przez Bert’a i innych [12], prawie wszystkie kobiety objęte obserwacją (95\%) okazały się korzystać z Internetu jako źródła informacji medycznych, przy czym niektóre z nich pozyskiwały wiedzę również od profesjonalistów. Główną przyczyną korzystania z Internetu w poszukiwaniu wiedzy medycznej była potrzeba pogłębienia wiadomości na tematy związane z ciążą [12]. Jednocześnie temat ciąży jest jednym $\mathrm{z}$ najczęściej wyszukiwanych w Internecie przez ankietowanych z grupy kobiet jak i mężczyzn, co potwierdziły badania przeprowadzone przez Liama-Pereria, mówiące o tym, że 97,7\% użytkowników Internetu wyszukiwało w nim jakichkolwiek informacji na jej temat, a $26,9 \% \mathrm{z}$ nich robiło to $\mathrm{w}$ ciągu 24 godzin wstecz [13]. Natomiast badania przeprowadzone przez Stephanie Wallwiener i innych [14] na grupie 220 ciężarnych korzystających z usług medycznych w dwóch uniwersyteckich szpitalach na terenie Niemiec dowiodły, że 50,8\% ankietowanych kobiet korzysta z Internetu w celu wyszukania informacji na temat prawidłowego przebiegu ciąży, porodu i połogu, $22,4 \%$ ankietowanych 
wykorzystuje w tym celu tylko aplikacje , a 16,2\% korzysta $\mathrm{z}$ obu tych źródeł. Jednocześnie wywnioskowano, że kobiety korzystające $\mathrm{z}$ aplikacji ciążowych są młodsze, a wpływ wyszukiwanych przez nie informacji jest znaczny [14]. Kolejne badania przeprowadzone w Chinach dowiodły, że większość kobiet $(81,5 \%)$ wyszukuje informacje w tych źródłach na początku ciąży [15], co pokrywa się z badaniami przeprowadzonymi we Włoszech. Tamtejsze ankietowane kobiety ciężarne najczęściej szukają odpowiedzi na nurtujące je pytania w pierwszym trymestrze ciąży [16].

W Polsce brakuje badań nt. wykorzystywania aplikacji mobilnych przez kobiety ciężarne. Nie sposób jednak bagatelizować fakt, że szeroki wybór i rozpowszechnienie aplikacji medycznych dotyczących zdrowia kobiet w każdym wieku rzutuje na współpracę między kobietą, a położną. Położna jako pracownik ochrony zdrowia funkcjonujący najbliżej z kobietami, ma decydujący wpływ na edukację przedkoncepcyjną, prenatalną oraz wieku przekwitania. Znaczącą rolę wspomagającą i uzupełniającą w przekazywaniu informacji przez położne ma Internet oraz programy mobilne. Przystępna forma dostępu do wiedzy wzbogaca położną o funkcjonalne narzędzia, dzięki którym edukacja zdrowotna jest ciągła. Fakt, że pacjentki korzystają $\mathrm{z}$ aplikacji medycznych w monitorowaniu swojego stanu zdrowia, powoduje zwiększenie dokładności zapisu daty i czasu wystąpienia konkretnych objawów, dzięki czemu można je powiązać z konkretnymi zburzeniami w trakcie diagnozowania patologii. Położne rodzinne, świadome wykorzystywania aplikacji medycznych przez kobietę, są w stanie zaufać jej w sprawie samokontroli. Również funkcje oferowane przez aplikacje usprawniają przeprowadzenie edukacji zdrowotnej w przystępny i wygodny sposób. Na bieżąco wyświetlające się komunikaty o możliwie występujących objawach w danym okresie zmniejszają też narażenie pacjentki na niepotrzebny stres, co umożliwia położnym skupienie się na prawdopodobnie niepokojących je objawach, a nie ciągłe rozwiewanie wątpliwości pacjentek. Dzięki łatwo dostępnym i czytelnym wskazówkom na temat samodzielnego badania piersi, będących uzupełnieniem i przypomnieniem informacji uzyskanych w ramach edukacji zdrowotnej, położne mają możliwość pozostawienia kontroli zdrowia w rękach kobiet. Powodzenie działań uświadamiających jest większe, kiedy komunikaty naświetlające nieprawidłowości znajdują się na wyciągnięcie ręki pacjentki.

Zainteresowanie aplikacjami i internetem ma bardzo duży wpływ na kobiety i wciąż rośnie, jednak nierzadko są to źródła wciąż mało wiarygodne. W badaniu przeprowadzonym przez Rezniczka i innych [17], tylko 4,2\% niemieckojęzycznych stron dotyczących problemów ginekologicznych może być ocenione jako dobre, a badanie przeprowadzone przez Berta i innych [18] stanowi, że tylko połowa $z$ najbardziej popularnych ciążowych aplikacji podaje źródło zawartych w nich informacji.

Wykorzystanie aplikacji mobilnych jako narzędzie do pozyskiwania informacji zdrowotnych przez kobiety to stosunkowo młode zjawisko, jednakże już teraz dostrzec można znaczący wpływ na zdrowie kobiet. Wobec powyższego, na potrzeby tej pracy przeprowadzono przegląd funkcji proponowanych przez najpopularniejsze aplikacje do monitorowania cyklu miesiączkowego, monitorowania ciąży i profilaktyki raka piersi dostępnych na platformie Google Play. Są to aplikacje pozwalające kontrolować zmiany zachodzące w organizmie kobiet oraz zawierają wskazówki dotyczące postępowania w przypadku wykrycia patologii.

\section{WNIOSKI}

W grupie analizowanych aplikacji mobilnych pomocnych w kontroli cyklu miesiączkowego, aż 83\% posiada zakres funkcji oferowanych przez producentów i ułatwiających samodzielną kontrolę przez kobiety. Niższe wskaźniki funkcji (63\%) występują w grupie aplikacji pomocnych w monitorowaniu ciąży i jeszcze niższe w grupie profilaktyki chorób. Mobilne aplikacje zdrowotne stanowią obiecującą strategią edukacji zdrowotnej jako narzędzie monitorowania, poprawiania samokontroli oraz zwiększenia świadomości w opiece nad kobietami, jakkolwiek brak formalnych regulacji w zakresie potwierdzania wiarygodności dostępnych aplikacji zdrowotnych wskazuje na potrzebę wzmożonej czujności przez kobiety oraz pracowników ochrony zdrowia.

\section{ORCID}

\section{Barbara Ślusarska (iD https://orcid.org/0000-0003-0101-9216}

\section{REFERENCES/PIŚMIENNICTWO}

1. Jerpil. Mobile Phones and Society - How Being Constantly Connected Impacts Our Lives. The Mobile. 2013. Issue 29: Available at: http://source.southuniversity. edu/mobile-phones-and-society-how-being-constantly-connected-impacts-ourlives-137313.aspx (accessed 10. 10.2019)

2. Santoro E, Castelnuovo G, Mauri G, Sicurello F. Social Media and Mobile Applications in Chronic Disease Prevention and Management. Front Psychol.2015; 6 :567. doi: 10.3389/fpsyg.2015.00567.eCollection 2015.

3. Research2Guidance. mHealth App Developer Economics 2016. The current status and trends of the mHealth app market. 2016. Available at: https://research2guidance. com/r2g/r2g-mHealth-App-Developer-Economics-2016.pdf (accessed 18 August 2019).

4. Research2Guidance. mHealth App Economics 2017/2018: Current Status and Future Trends in Mobile Health. 2017. Available at: https://research2guidance.com/wpcontent/uploads/2017/11/R2G-mHealth-Developer-Economics-2017-Status-AndTrends.pdf (accessed 18 August 2019).

5. www.itgenerator.pl. 2019. Aplikacjemobilne w branżymedycznej.https://www. itgenerator.pl/wp-content/uploads/2019/02/ITgenerator_branza_medyczna.pdf. (accessed 20 August 2019).

6. Bujanowska-Fedak M, Tomczak M, Pokorna-Kałwak D. Zastosowanie nowoczesnych technologii mobilnych w opiece zdrowotnej wyzwaniem dla XXI wieku. PulsUczeni. 2016; (10) 2: 37-43.

7. Aguilera A, Muench F. There's an app for that: information technology applications for cognitive behavioral practitioners. BehavTher. 2012; 35(4):65-73.

8. Stančič Z. European Commission. The myhealthappsdirectory 2015-2016. Featuring health apps that focus on care in the community, disability, health, and wellness - a review by patient groups and empowered consumer. 2016. PatientView,PDF. http://www.patient-view.com/uploads/6/5/7/9/6579846/_the_myhealthapps_ directory_2015-2016.pdf. (accessed 12 0ctober 2019).

9. Arak P, Bobiński A, Wójcik A. Rynek urządzeń i aplikacji mobilnych w Polsce, w: Chyckowska A. (red.), Bez kabli. Mobilny Internet motorem zmian społecznych i ekonomicznych, Polityka Insight, Warszawa; 2015.

10. World Health Organization. mHealth: new horizons for health through mobile technologies. Global Observatory for eHealth series. 2011; vol 3.Available at: https:// www.who.int/goe/publications/goe_mhealth_web.pdf. (accessed 12 August 2019). 
Monika Walec, Natalia Surma, Weronika Michoń, Barbara Ślusarska

11. Kraschnewski JL, Chuang CH, Poole ES, et al. Paging, "Dr. Google": does technology fill the gap created by the prenatal care visit structure? Qualitative focus group study with pregnant women. J Med Internet Res. 2014; 16(6):e147.

12. Bert F, Gualano MR, Brusaferro $S$, et al. Pregnancy e-health: a multicenter Italian crosssectional study on internet use and decision-making among pregnant women. J Epidemiol Commun Health. 2013; 67(12):1013-1018

13. Lima-Pereira P, Bermu'dez-Tamayo C, Jasienska G. Use of the Internet as a source of health information amongst participants of antenatal classes. 2012; 21(3-4):322330

14. Wallwiener S, Muller M, Doster A, et al. Pregnancy eHealth and mHealth: user proportions and characteristics of pregnant women using Web-based information sources - a cross-sectional study. Arch GynecolObste. 2016; 294: 937-944 DOI 10.1007/s00404-016-4093-y

15. Gao L, Larsson M, Luo S. Internet use by Chinese women seeking pregnancy-related information. Midwifery. 2013; 29(7):730-735.

16. de Santis M, de Luca C, Quattrocchi T, et al. Use of the internet by women seeking information about potentially teratogenic agents. Eur J ObstetGynecolReprod Biol. 2010; 151(2): 154-157.

17. Rezniczek GA, Küppers $L$, Heuer $H$, et al. Quality of websites of obstetrics and gynecology departments: a cross-sectional study. BMC Pregnancy Childbirth. 2015; 15(1):103-14. DOI 10.1186/s12884-015-0537-9

18. Bert F, Passi S, Scaioli G, et al. There comes a baby! What should I do? Smartphones' pregnancy-related applications: a web-based overview. Health Inform J. 2016; 22(3):608-17. DOI: 10.1177/1460458215574120.
Manuscript received/Praca zgłoszona do czasopisma: 15.11.2019

Manuscript accepted/Praca zaakceptowana do druku: 07.01.2020

Translation/Tłumaczenie: Berenika Walec 